\title{
Indonesian and Malaysian Governments' Policies towards COVID-19 Responses
}

\author{
Mariane Delanova ${ }^{1}$, I Wayan Aditya Harikesa ${ }^{2}$ \\ \{mariane.delanova@gmail.com ${ }^{1}$, wayan.aditya@lecture.unjani.ac.id ${ }^{2}$ \} \\ Universitas Jenderal Achmad Yani, Jawa Barat, Indonesia ${ }^{1}$, Universitas Jenderal Achmad Yani, Jawa \\ Barat, Indonesia ${ }^{2}$
}

\begin{abstract}
The COVID 19 pandemic began in Wuhan, Hubei, China, was first reported at the end of 2019. Furthermore, this virus has spread into various parts of the world; at least the spread of the SARS-CoV-2 virus occurred in 213 countries, including Indonesia and Malaysia. In both countries, Indonesia and Malaysia, until 15 September 2020, bringing the total positive cases to 225,030 and 10,052 respectively. Therefore, regarding with handling of COVID-19, both countries need to regulate a specific policy to prevent the increase of COVID-19 cases. Hence, this paper aims to compare government regulation in both countries suitable for handling this pandemic. Using qualitative methods, the authors will mention a brief policy by analyzing an exact document to give a deeper analysis of government policies.
\end{abstract}

Keywords: COVID-19, Indonesia and Malaysia, Government Regulations

\section{Introduction}

From February to June 2020 during the period, the world has been struck by the worst pandemic in which humanity have facing. Namely SARS-CoV-2 or COVID-19, the first record of the virus occurring or began in Wuhan, Hubei province, China at the end of 2019 and the impacts of the spreads of this virus is globally. The COVID-19 shock has dominated policy discussion in two major sectors in which are health and economic sector. The health sector become issues of greatest concern and focus for worldwide government to handle, because this virus attacks the respiratory tract and almost one-third of the people around the world reported death, in other words the mortality rates increasing to $30 \%$ total world population. More importantly in economic issues caused by COVID-19 spreads is exceedingly fast, it impacts most of economic growth sector such as education and public sector (schools, colleges, factory, malls, traditional markets, transportations, and many as well) - many economic sectors have been shut down - thus, it seriously impacts the labor force as well as well-being of the world society. The authors therefore intend to compare two national government policies in this paper: the Indonesian and Malaysian governments in response to the COVID-19 pandemic. The purpose of this paper is to discuss the policies developed by both countries to prevent COVID-19 from spreading.

\section{Literature Review}


Prior we discuss about both governments of Indonesia and Malaysia regulations in response of COVID-19 spreads, there is a brief section that authors will provide about current situation of COVID-19. A journal of medicine from Ferguson, suggesting that COVID-19's impact is very fatal [1]. The US Centers for Disease Control and Prevention (CDC) reported at the end of May that about one third of symptomatic infections with coronavirus and about $0.4 \%$ of people died with an infection-related death rate (IFR) below 0.3 . Percent [2].

Previous reports, on the other hand, indicate that COVID-19 is 30 times more lethal than the influenza-causing virus and at least 10 times more infectious than the previous SARS virus [3]. The world, specifically many countries responded to the COVID-19 outbreak as well as regulating the emergency-fast response regulation depends on the current situation of those countries such as People Republic of China, Italy, France, etc. Many countries responded by issuing the lockdowns regulation to prevent the spreads, of COVID-19. However, by issuing the lockdowns order or regulation, it impacts on economic as well as health issues.

\subsection{COVID-19's Deaths Toll Around the World}

As well as the complexity of the situation and socio-economic circumstances. The comparison of health impacts around the world is affected by two other alerts. Second, the COVID-19 health hazard, where most of the people who died were over 50 years of age and older. This is an age that, particularly with a history of other complications, is very vulnerable to viruses. An international analysis by Docherty et al. (2020) found that the number of at-risk deaths for those over 65 years of age was 65 percent higher than average and 82 percent higher than usual for those over 75 years of age, respectively [4]. These data for cause of the deaths reflect the fact that COVID-19 may kill indirectly if people are not treated for other conditions caused by overloaded hospitals.

Second, in the Italian region, the COVID-19 death rate in Lombardy is 1,500 per million people. Compared to 300 per million cases elsewhere in Italy, this is a very good ranking. Similarly, the death rate reached 1.410 per million people in New York City. Data reveals the death rate is 76 per million in other parts of the world, such as China. Meanwhile, most of the deaths due to COVID-19 in Indonesia occurred in large cities such as Central Jakarta and many parts of East Java, which in the fourth quarter of 2020 reached 3,635 cases per million [5].

The international COVID-19 cases and deaths database reports do not adhere to the age structure of the country or the clustering nature of the disease. However there are other variables that affect the comparison of case rates in these countries, including variations in testing rates [5]. The numerous conditions for the recording of deaths. Official data shows that the impact of COVID-19 in Indonesia is not as severe as in many other countries (see table 1).

Table 1 Reported Cases and Deaths of COVID-19 (as of 17 September 2020)

\begin{tabular}{|c|c|c|c|c|}
\hline & $\begin{array}{c}\text { Confirmed } \\
\text { cases }\end{array}$ & Deaths & $\begin{array}{c}\text { Case } \\
\text { fatality } \\
\text { rate }\end{array}$ & $\begin{array}{c}\text { Total } \\
\text { recovered } \\
\text { cases }\end{array}$ \\
\hline \multicolumn{5}{|c|}{10 most affected countries } \\
\hline $\begin{array}{l}\text { United } \\
\text { States }\end{array}$ & $6,761,008$ & 201,000 & 5.50 & $3,66,000$ \\
\hline Brazil & 910,221 & 135,000 & 4.90 & $3,750,000$ \\
\hline
\end{tabular}




\begin{tabular}{lcccc} 
Russia & 588,812 & 19,061 & 1.30 & 896,000 \\
India & 365,778 & 83,198 & 2.90 & $4,030,000$ \\
United & 315,189 & 41,705 & 14.00 & - \\
Kingdom & & & & \\
Spain & 246,198 & 30,405 & 11.10 & 208,000 \\
Italy & 251,290 & 35,658 & 14.50 & 216,000 \\
Peru & 231,992 & 31,051 & 2.90 & 123,205 \\
France & 191,304 & 31,095 & 15.20 & 31,095 \\
Iran & 189,876 & 23,808 & 4.70 & 23,808 \\
Selected Asian Countries & & & \\
China & & & 5.50 & \\
Singapore & 57,532 & 27 & 0.10 & 57,039 \\
Indonesia & 233,00 & 9,222 & 5.60 & 167,000 \\
Philippines & 276,000 & 4,785 & 4.20 & 7,133 \\
South & 22,657 & 372 & 2.30 & 19,543 \\
Korea & & & & \\
Malaysia & 8,922 & 121 & 1.40 & 8,122 \\
Thailand & 3,315 & 79 & 1.90 & 3,212 \\
Vietnam & 334 & 0 & 0.00 & 325 \\
World & $30,123,000$ & 487,931 & 5.41 & $20,410,100$ \\
\hline \multicolumn{2}{r}{ Source: John Hopkins University, 2020} & & &
\end{tabular}

Cases and deaths peaked in other developing countries in early September, such as Italy, France and the UK. After that a number of developing countries such as India and Peru, joined the list of 10 seriously affected countries.

But no Asian nation was in the top 10 in Wuhan, China, and the initial epidemic of sick people traveling to neighboring nations. While Singapore has the highest number of confirmed cases in Southeast Asia, the recovery rate is relatively high (see table 1).

\subsection{COVID-19's Impact on GDP}

In order to reduce the spread of COVID-19 across the country, several countries have taken policy measures to close their borders and restrict the movement of the population. The same strategy known as the "lockdown," is applied by the Indonesian state. However, this only applies in a few areas, especially in big cities and national capitals. In China, throughout Hubei province, the government has put Wuhan's (11 million people) on lockdown and restricted movement. According to data from the International Air Transport Organization, more than 156 countries around the world have imposed limits on travel to their countries, denied entry to foreign visitors, restricted visas for both student visas and visitor visas, and imposed compulsory quarantines on returning native nationals from abroad. And they showed viral symptoms [6].

The presence of this government policy reduces the supply of labor, especially foreign skilled workers. On the other hand, current social distancing, either required or resulting from preventive options made by central and regional governments, affects productive capacity and competitiveness [7]. In the fourth quarter of 2020, the IMF forecasts that the global economy 
will undergo a 3 percent contraction. The socio-economic instability in the economies of countries within the OECD (Organization for Economic Co-operation and Development) is projected to be the largest (see table 2). However the IMF estimates that GDP growth will continue to last until the end of this year for several countries including Indonesia, Malaysia, China, India, Vietnam and the Philippines [8].

Table 2 Revised IMF Growth Projections (\%)

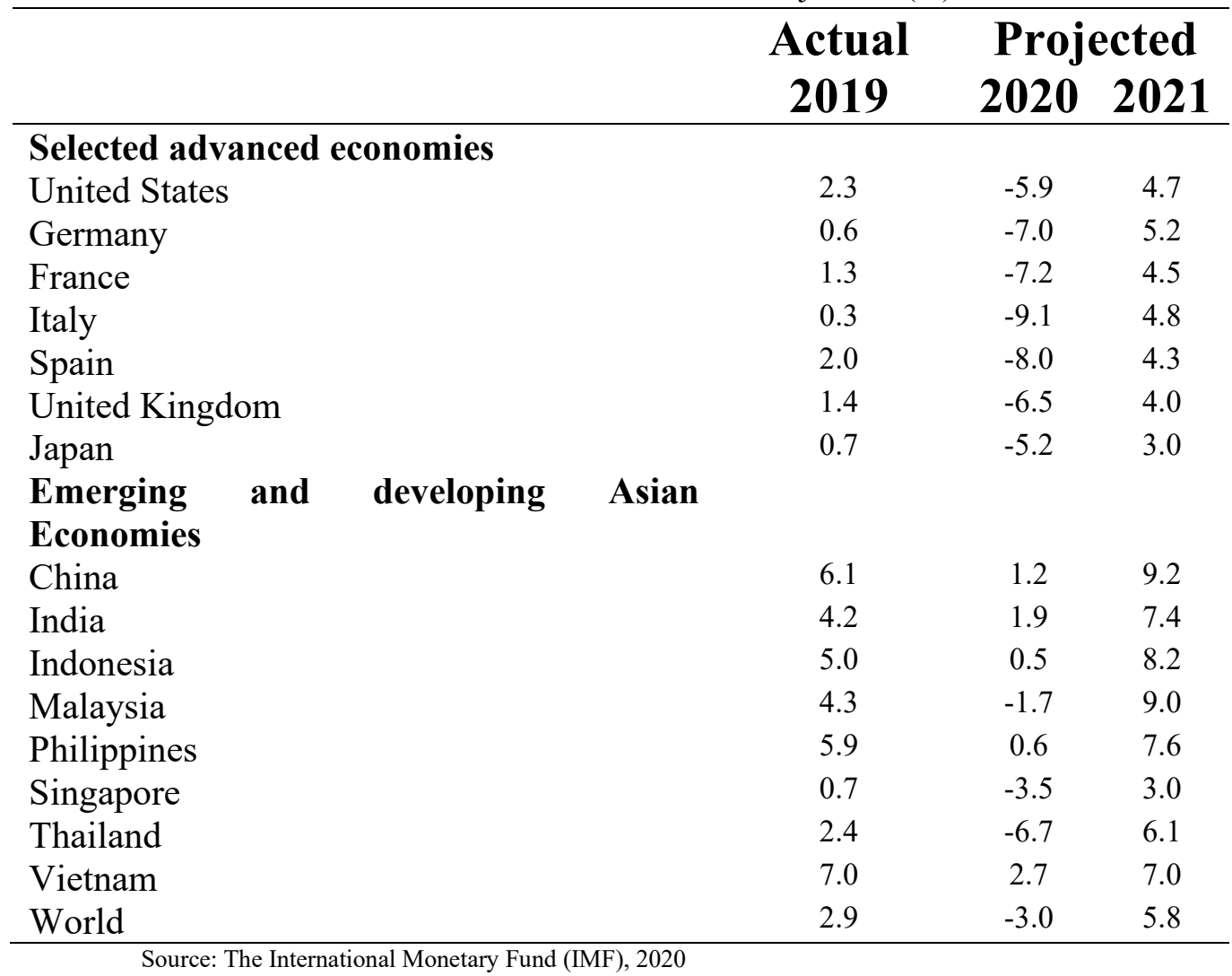

On the basis of the data in Table 2, GDP shocks in global trade are projected to decline by between $13 \%$ and $32 \%$ in 2020 , also due to the tension created by the US president in the conflict with China. However it also hurts other exporting countries in East Asia, given China's increasing position as an export destination for consumer and intermediate goods and trade security [9].

\section{Methodology}

In this paper, authors use qualitative methods by compare Indonesian and Malaysian government regulations focusing on COVID-19 response. This method seeking data by comparison ways and analyze deeper about the government regulations of both countries. 
Through comparison, authors argue it will be more suitable related to analyze reports as well as news about the implementation of policies in which implemented by the two countries. Hence, through qualitative methods, the author argues that we can read data through a measurement scale regarding the spread and impact generated by the spread of the corona virus.

\section{Discussion}

The world is currently impacted by the novel coronavirus disease (COVID-19). The global COVID-19 pandemic began in Wuhan, Hubei, China, was first reported at the end of 2019. Furthermore, this virus has spread to various parts of the world, at least the spread of the SARS-CoV-2 virus occurred in 213 countries, including Indonesia. As of September 2020, the spread of the SARS-CoV-2 virus is still ongoing in Indonesia with additional cases per day. As of September 15, 2020, there were 29,417,244 people infected with COVID 19 worldwide, with global reported deaths of 931,976 people or about four percent of the total cases [10]. In Indonesia, additional daily cases reached 3,507 cases on September 15, 2020, bringing the total positive cases to 225,030 since the first infected individual case in Indonesia on March 2, 2020.

After the first case study of the Covid-19 case in Indonesia in early March, instead of Law No. 1 of 2020 (PERPU 01/2020) on State Financial Policy and Financial System Stability for the Handling of the 2019 Corona Virus Pandemic, the Indonesian government has released a Government Regulation (COVID-19) and/or in the sense of coping with challenges to the national economy and/or the stability of the financial system [11]. The total budget allocated by the Government of Indonesia to deal with the COVID-19 pandemic is IDR 405.1 Trillion.

Furthermore, on April 3, 2020, the President again issued Presidential Regulation Number 54 of 2020 concerning Posture Changes in Details and the 2020 State Budget (APBN). This Presidential Regulation is a further response from the Government of Indonesia. In addition to issuing laws and regulations, the Indonesian Government has also formed a Rapid Action Team (TGC) in the territory of the state entrance authority at airports, ports and national land border posts (PLBDN) the Ministry of Health has appointed at least 100 referral hospitals that have been used. as a referral hospital for bird flu cases, the Government of the Republic of Indonesia has also decided to delay flights to and from China from 5 February 2020 and many responses in the form of other policies issued by the Government of Indonesia in overcoming the spread of the COVID 19 pandemic.

One of the policies that has had a significant impact on various aspects of people's life in Indonesia is the policy of implementing Large-Scale Social Restrictions (PSBB). PSBB is based on Government Regulation Number 21 of 2020 concerning Large-Scale Social Restrictions in the context of the Acceleration of Handling of Corona Virus Disease 2019 which was set starting on March 31, 2020 [12]. This decision gives the Regional Government flexibility to impose PSBB for one particular province, regency and city respectively. The enforcement of the PSBB must be based on a recommendation from the Governor or Regent or Mayor submitted to the Minister of Health. PSBB policies refer to Regulation of the Minister of Health Number 9 of 2020 concerning PSBB Guidelines, "(2) Restrictions on religious practices; (3) Restrictions on activities in public places or facilities; (4) Restrictions on socio- 
cultural activities; (5) Restrictions on modes of transport; and (6) Restrictions on other activities related to aspects of defence and security. Therefore, limiting group events outside the home is the core of the PSBB policy. When there is no immediate need to leave home, people are supposed to stay at home (work from home, study at home) [12]."

Otherwise, in Malaysia, the COVID-19 pandemic began to enter on January 23, 2020. Continually, the Royal Malaysian Government immediately responds to the handling of COVID-19 by carrying out various policies. The policy carried out by the Malaysian Government is to carry out two methods that "go hand in hand", namely the Movement Control Order (MCO) and the testing. In fact, Malaysia was the first country to implement a national-scale lockdown policy compared to other countries in the Southeast Asia region, which was announced on March 16, 2020 and implemented from March 18 to June 9, 2020. In addition, the $\mathrm{MCO}$ is a policy to totally prohibit meeting activities that involve many people, including religious activities, the closure of all educational institutions, travel restrictions for both Malaysian and foreign citizens, and the closure of private and state companies (except for businesses related to basic services).

The MCO policy is accompanied by policies for conducting testing and contact tracing. The capacity to conduct tests has increased from 3,500 tests per day to 11,500 in early April and in early May, the Malaysian Ministry of Health (KKM) can conduct as many as 22,000 tests per day [13] The combination of these two policies is also referred to as the "twin approaches" which are considered to bring positive results. Positive results can be seen from the increase in the number of positive cases of COVID-19 in Malaysia which is not too significant. On 15 September 2020 it was reported that there were 23 new cases of COVID-19 infection, bringing the total positive cases in Malaysia to 9,969 people with a death toll of 128 [14]. The number of positive cases and deaths due to COVID-19 infection in Malaysia and Indonesia has a significant difference.

Therefore, the aims of this paper are not specifically mention about all the government policies in both countries. However, authors will describe about the effectiveness of both countries' regulation in response of COVID-19 spread. Further, by choosing the existing policies from Indonesia and Malaysia, we are able to compare what is the effective as well as the ineffective policies.

The implementation of the MCO policy in Malaysia is accompanied by the provision of sanctions, namely for people who violate the MCO policy will be subject to a maximum fine of RM 1,000 or a maximum of six months' imprisonment. The penalty or imprisonment is written in the Federal Government Gazette dated March 18, 2020 under the title Regulation 2020 Prevention and Control of Infectious Diseases [15]. Otherwise, in Indonesia, the PSBB policy as stipulated in Government Regulation Number 21 of 2020 concerning Large-Scale Social Restrictions (PSBB) does not specify sanctions or fines that will be imposed on people who violate PSBB policies. Other legal umbrellas such as PERPU 01/2020 concerning State Financial Policy and Financial System Stability for Handling the Corona Virus Disease 2019 (COVID-19) Pandemic or in the Context of Facing Threats that Endanger the National Economy or Financial System Stability contains the total budget that is allocated for this pandemic is Rp. 405.1 Trillion, in which the detailed budget is stipulated in Presidential Decree No. 54 of 2020 concerning Posture Changes in Details and the 2020 State Budget [11]. The content of the Presidential Regulation is that the ministry's budget is cut by 97.42 trillion, but there are several ministries that have experienced an increase in the budget, namely the Ministry of Health from IDR 57 trillion to IDR 76 trillion and the Ministry of Education and Culture from IDR 36 trillion to IDR 70 trillion [16]. 
The policy for handling the spread of the COVID-19 pandemic in Malaysia is accompanied by the imposition of strict sanctions or fines. This causes the community to comply with the MCO policy implemented by the Malaysian Government. Meanwhile, in Indonesia, the PSBB policy as a policy undertaken by the Government of Indonesia to suppress the spread of the SARS-CoV-2 virus without being accompanied by sanctions or fines as stated in the legal basis of the PSBB policy causes the Indonesian people to be not disciplined and comply with the PSBB policy. The day before the Indonesian Government announced the ban on going home or traveling between cities or provinces, people in Indonesia immediately went home to their hometowns of origin, causing a surge in buses or public transportation [17]. Not to mention the cases where people actually do various tricks in order to go home, ranging from taking the "mouse route" or an unusual route to hiding in a truck [18].

\section{Conclusion}

The COVID-19 or Coronavirus needs greater attention to be handling. Its impact of spreads is fatal and distorted all vital sectors of health and economic sectors. Farmers are generally older than other workers in both Indonesia and Malaysia. Thus COVID-19 may pose a greater risk to their health as well as their economy. Moreover, the food chain's leading procedures, especially rice and meat, are needed to give more attention. Both Indonesian and Malaysian governments need to take more seriously on farmers; thus, if Indonesia and Malaysia's government did not take immediate action, this would be creating poverty and famine across both countries.

To sum up, Indonesia and Malaysia have a regulation in handling or the response of COVID-19 spreads. Both governments already have a fast response team and formulate regulations that "needs to be done" immediately. Authors argue that Indonesia and Malaysia are positive; Indonesia already has large-scale social restrictions or PSBB policy. However, in contrast to the Malaysian government, which implements the Movement Control Order (MCO) policy, the Indonesian government does not strictly impose clear fines. Thus, PSBB policy needs to be stricter to prevent coronavirus spreads. Finally, the authors hope that this pandemic situation will quickly end and restore both the health and economic sector.

\section{References}

[1] N. Ferguson et al., "Report 9 - Impact of non-pharmaceutical interventions (NPIs) to reduce COVID-19 mortality and healthcare demand | Faculty of Medicine | Imperial College London," Imp. Coll. COVID Response Team, no. March, p. 20, 2020.

[2] P. Poletti et al., "Probability of symptoms and critical disease after SARS-CoV-2 infection," Jun. 2020.

[3] A. Wilder-Smith, C. J. Chiew, and V. J. Lee, "Can we contain the COVID-19 outbreak with the same measures as for SARS?," Lancet Infect. Dis., vol. 20, no. 5, pp. e102-e107, 2020.

[4] P. D. Sugiyono, “済無No Title No Title,” J. Chem. Inf. Model., vol. 53, no. 9, pp. 1689-1699, 2016.

[5] E. Bendavid et al., "COVID-19 Antibody Seroprevalence in Santa Clara County, California," medRxiv, p. 2020.04.14.20062463, Apr. 2020.

[6] "IATA - International Travel Document News," 22-Sep-2020. [Online]. Available: https://www.iatatravelcentre.com/world.php. [Accessed: 22-Sep-2020]. 
[7] P. Bofinger et al., "Economic implications of the COVID-19 crisis for Germany and economic policy measures," The Graduate Institute Geneva. p. 11, 2020.

[8] IMF, WORLD ECONOMIC OUTLOOK INTERNATIONAL MONETARY FUND The Great Lockdown, no. May. 2020.

[9] S. Olivia, J. Gibson, and R. Nasrudin, "Indonesia in the Time of Covid-19," Bull. Indones. Econ. Stud., vol. 56, no. 2, pp. 143-174, 2020.

[10] F. Al-Qodariah, "[UPDATE] Kasus Virus Corona Indonesia per 13 September 2020 Naik Jadi 218.382 Orang - Pikiran-Rakyat.com," Pikiran Rakyat.com, 13-Sep-2020. [Online]. Available: https://www.pikiran-rakyat.com/nasional/pr-01739346/update-kasus-virus-corona-indonesia-per13-september-2020-naik-jadi-218382-orang?page=3. [Accessed: 22-Sep-2020].

[11] Kementerian Keuangan Republik Indonesia, "PERPU No. 1 Tahun 2020 tentang Kebijakan Keuangan Negara dan Stabilitas Sistem Keuangan untuk Penanganan Pandemi Corona Virus Disease 2019 (COVID-19) dan/atau dalam Rangka Menghadapi Ancaman yang Membahayakan Perekonomian Nasional dan/atau Stabilitas Sistem Keuangan [JDIH BPK RI]." [Online]. Available: https://peraturan.bpk.go.id/Home/Details/135060/perpu-no-1-tahun-2020. [Accessed: 22-Sep-2020].

[12] A. P. Taher, "Jokowi: Lockdown Bisa Hentikan Ekonomi, Pemda Jangan Berlebihan - Tirto.ID," 01-Apr-2020. [Online]. Available: https://irto.id/jokowi-lockdown-bisa-hentikan-ekonomi-pemdajangan-berlebihan-eKcD. [Accessed: 22-Sep-2020].

[13] E. Zainul, "Malaysia to reach 22,000 Covid-19 tests per day by next week | The Edge Markets," 27-Apr-2020. [Online]. Available: https://www.theedgemarkets.com/article/malaysia-reach-22000covid19-tests-day-next-week. [Accessed: 22-Sep-2020].

[14] H. H. Salengke, "Malaysia Laporkan 23 Kasus Covid-19 Baru, Klaster Baru Muncul," 15-Sep2020. [Online]. Available: https://mediaindonesia.com/read/detail/345110-malaysia-laporkan-23kasus-covid-19-baru-klaster-baru-muncul. [Accessed: 22-Sep-2020].

[15] S. . Kurniawan, "Melanggar perintah pembatasan, Malaysia jatuhkan sanksi denda dan pidana," 18-Mar-2020. [Online]. Available: https://internasional.kontan.co.id/news/melanggar-perintahpembatasan-malaysia-jatuhkan-sanksi-denda-dan-pidana. [Accessed: 22-Sep-2020].

[16] Kemenlu, "KEBIJAKAN PEMERINTAH REPUBLIK INDONESIA TERKAIT WABAH COVID-19," 31-Mar-2020. [Online]. Available: https://kemlu.go.id/brussels/id/news/6349/kebijakan-pemerintah-republik-indonesia-terkait-wabahcovid-19. [Accessed: 22-Sep-2020].

[17] M. Niman, "Sehari Sebelum Dilarang Mudik, Terjadi Lonjakan Penumpang Bus," 24-Apr-2020. [Online]. Available: https://www.beritasatu.com/jaja-suteja/megapolitan/625031/sehari-sebelumdilarang-mudik-terjadi-lonjakan-penumpang-bus. [Accessed: 22-Sep-2020].

[18] P. S. Paritiwi, "Jokowi Imbau Masyarakat Bekerja dan Beribadah di Rumah," 15-Mar-2020. [Online]. Available: https://www.cnnindonesia.com/nasional/20200315141316-32-483586/jokowiimbau-masyarakat-bekerja-dan-beribadah-di-rumah. [Accessed: 22-Sep-2020]. 